\title{
PROGRAM PENGABDIAN MASYARAKAT: PENGELOLAAN HUTAN BAKAU DENGAN PENDEKATAN BANK SAMPAH
}

\author{
Dian Alfia Purwandari ${ }^{1)}$, Shahibah Yuliani ${ }^{2)}$, dan Nova Scorviana H. ${ }^{3)}$ \\ ${ }^{1,2,3}$ Program Studi Pendidikan IPS, Fakultas Ilmu Sosial, Universitas Negeri Jakarta \\ 1,2,3 J1. Rawamangun Muka, RT.11/RW.14, Rawamangun, Pulo Gadung, Kota Jakarta Timur, DKI Jakarta 13220 \\ E-mail : dian-alfia@unj.ac.id ${ }^{1)}$, s.yuliani@unj.ac.id ${ }^{2)}$, nova.scorviana@unj.ac.id ${ }^{3)}$
}

\begin{abstract}
ABSTRAK
Kegiatan pembentukan Bank Sampah di daerah pesisir ini beryujuan untuk mengelola sampah anorganik. Sampah anorganik tersebut merupakan permasalahan yang menyebabkan terhalangnya konservasi hutan bakau yang ada di desa Segara Jaya, Kecamatan Tarumajaya, Kabupaten Bekasi. Permasalahan ini diatasi dengan pembentukan kegiatan yang berbasis partisipasi masyarakat berupa Bank Sampah. Kegiatan ini diawali dengan identifikasi permasalahan dan merancang bentuk bank sampah yang melibatkan masyarakat setempat. Bank sampah Jembatan Cinta terbentuk dengan pendekatan partisipasi masyarakat yang melibatkan masyarakat secara keseluruhan sebagai pengelola untuk kemandirian. Diawal kegiatan, kendala yang dihadapi oleh pengelola didasari oleh pemahaman masyarakat yang belum mengenal prinsip dasar bank sampah dengan baik walau kegiatan diawali dengan penyuluhan. Namun, dengan pendekatan langsung kepada masyarakat permasalahan tersebut dapat diatasi.
\end{abstract}

Kata Kunci: Pengelolaan Hutan Bakau, Bank Sampah, Marine debris, Partisipasi Masyarakat

\section{PENDAHULUAN}

Lingkungan pesisir Indonesia tidak dapat lepas dari berbagai permasalahan lingkungan khususnya sampah. Sampah yang ada di daerah pesisir tidak hanya berasal dari kehiatan masyarakat di daerah pesisir saja, namun juga dapat berasal dari luar daerah pesisir bahkan dari lautan yang lebih dikenal dengan marine debris. Marine debris dapat mempengaruhi lingkungan secara langsung maupun secara tidak langsung. Permasalahan yang berkaitan dengan marine debris tidak hanya dialami oleh Indonesia namun di seluruh dunia (Hardesty dkkl. 2011), marine debris ini sangat berpengaruh terhadap lingkungan ekologi bahkan terhadap kehidupan biota yang hidup didalamnya (Williams, Ashe, and O'Hara 2011).

Hutan bakau di wilayah pesisir Indonesia sebesar 3 juta hektar yang merupakan $23 \%$ dari luas hutan bakau dunia (CIFOR 2015). Hutan Bakau yang dimiliki Kabupaten Bekasi tersebar di Kecamatan Muaragembong, Babelan dan Tarumajaya. Dari analisis yang dilakukan, luas wilayah hutan bakau dalam kurun waktu 59 tahun (1943-2006) telah mengalami penyusutan dan mengalami perubahan secara signifikan, dan luasnya tinggal 16,01 persen dari semula 10.000 hektare menjadi 1.580,05 hektare. Kabupaten Bekasi merupakan salah satu daerah yang mendapat bantuan dari program Gerhan periode 2003-2008. Secara berturut-turut pada tahun 2003 sampai 2006, daerah ini telah menerima bantuan bibit untuk rehabilitasi di Kecamatan Muaragembong, Babelan, dan Tarumajaya. Tetapi, mulai pada tahun 2006, Dinas Pertanian, Perkebunan dan Kehutanan Kabupaten Bekasi tak lagi menerima program bantuan tersebut. Sebab, saat itu bakau yang baru ditanam pada program tahun 2005 sudah mengalami kerusakan, sehingga dipertimbangkan untuk tidak menerima bantuan dulu sampai ada pemecahan (Septiarusli 2010).

Partisipasi masyarakat dalam merawat hutan bakau tergolong rendah (Yuliani and Herminasari 2017) dan diperparah dengan perilaku turis yang tidak memiliki kesadaran atas lingkungan (Haywantee Ramkissoon, Weiler, and Smith 2010; LEE, Jan, and Yang 2013; Puhakka 2011). Untuk itu perlu dirancang metoda yang tepat dalam pengelolaan sampah di hutan bakau.

Langkah awal dalam sebuah kegiatan adalah mencari permasalahan di lapangan dengan melibatkan masyarakat. Masyarakat diikutsertakan dalam merumuskan kegiatan pengelolaan hutan bakau berbasis partisipasi masyarakat sehingga meningkatkan kemandirian masyarakat dalam pengelolaan lingkungan hutan bakau.

\section{RUANG LINGKUP}

Kegiatan pengabdian ini untuk mengatasi permasalahan sampah yang dihasilkan oleh kegiatan pariwisata yang ada di Desa Segara Jaya, Kabupaten Bekasi. Namun, kagiatan ini hanya memfasilitasi sampah anorganik yang bertujuan agar masyarakat segarajaya mampu mandiri secara kegiatan dan keuangan serta lingkungan bakau yang lebih terjaga dengan adanya Bank sampah yeng terbentuk. 


\section{BAHAN DAN METODE}

Kegiatan Pengabdian kepada masyarakat di Desa Segara Jaya ini merupakan upaya dalam membentuk kemandirian masyarakat untuk mengelola lingkungannya. Untuk itu, masyarakat harus memahami pengetahuan dan keterampilan dalam mengelola permasalahan lingkungan.

\subsection{Bank Sampah}

Kegiatan peningkatan perlindungan mangrove Pantai Pal Jaya melalui model Bank Sampah membutuhkan partisipasi aktif dari masyarakat sekitar yang menjadi peserta penyuluhan maupun pelatihan.

Dalam pengelolaan hutan bakau yang baik diperlukan pendekatan yang diawali dengan pembentukan lembaga khusus. Setelah lembaga terbentuk, pengelolaan sampah dan pengendalian pencemaran sangat diperlukan dilanjutkan dengan penyuluhan dan pendidikan lingkungan masyarakat lokal (Lugina dkkl. 2017).

Pengelolaan sampah merupakan salah satu kegiatan yang dilakukan dengan cara pengumpulan, pengangkutan dan pemprosesan sampah secara daur ulang (Suryani n.d.). Pengelolaan sampah dan pengendalian pencemaran di hutan bakau dapat dilakukan dengan berbagai kegiatan. Salah satunya adalah bank sampah. Bank sampah merupakan pengelolaan sampah yang berbasis kemandirian masyarakat dari seluruh lapisan yang dapat melibatkan pemerintah, organisasi pemuda, PKK dan masyarakat (Marwati 2008).

\subsection{Tahapan Kegiatan}

Metode pelaksanaan dalam kegiatan ini dilakukan melalui penentuan masalah di Desa Segarajaya melalui proses identifikasi masalah berdasarkan riset terdahulu maupun observasi lapangan. Kemudian dilakukan solusi pemecahan masalah melalui peningkatan kapasitas masyarakat setempat dalam pemeliharaan kawasan mangrove melalui penyuluhan dan pelatihan pembuatan bank sampah, sebagai upaya model perlindungan kawasan pesisir pantai dan terakhir mendisain pelaksanaan program.

Setelah penentuan masalah dan penyuluhan, kegiatan pelaksanaan penyuluhan dan pelatihan bank sampah maupun gerakan pemeliharaan kawasan mangrove, terlebih dahulu dilakukan penyuluhan terhadap mitra dari kelompok masyarakat Pantai Pal Jaya, yakni: organisasi swadaya yang dikenal dengan Ikatan Pemuda Putera Daerah (IKAPUD), Kelompok Masyarakat Pengawas (POKMASWAS) dan masyarakat setempat yang didominasi dengan perempuan (pengurus PKK). Selanjutnya, pembentukan kader pengurus bank sampah, kegiatan penimbangan dan pencatatan, hingga pada tahap penjualan ke pengepul.

Dengan adanya kegiatan ini diharapkan semua pihak terkait mendukung sepenuhnya program ini baik secara kelembagaan, materiil maupun moril. Adapun skema/bagan alur pelaksanaan bank sampah yang disetor mitra pada pelaksana terdapat pada bagan berikut ini :

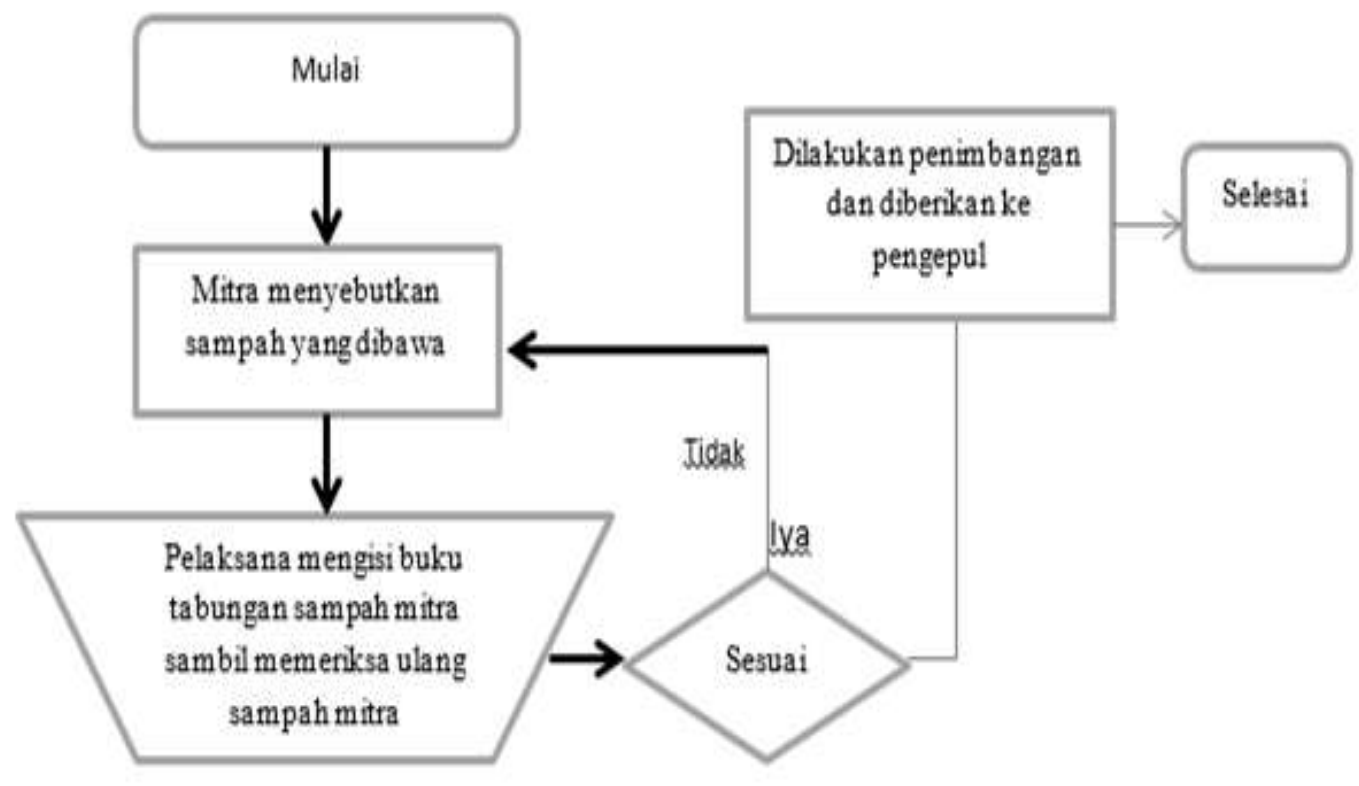

Gambar 1. Alur pelaksanaan bank sampah 


\section{PEMBAHASAN}

Pengabdian Kepada Masyarakat ini dilaksanakan melalui tiga tahap, pertama pada tanggal 21 Agustus 2018 berlokasi di Aula Desa Segara Jaya, masyarakat diberikan sosialisasi tentang perlindungan kawasan pesisir Pantai PAL Jaya Desa Segara Jaya, Tarumajaya, Bekasi mengenai lingkungan pesisir dan bahaya sampah bagi kehidupan manusia, ekosistem pesisir dan laut, serta pengelolaan sampah dalam bentuk bank sampah.

Kemudian kegiatan pengabdian yang kedua dilaksanakan pada hari Rabu, 19 September 2018, berlokasi masih di Aula Desa Segara Jaya. Dalam pertemuan yang kedua ini tim Pengabdian Kepada Masyarakat beserta tim ahli mengadakan pertemuan dengan perwakilan masyarakat yang pada pertemuan sebelumnya sudah mengikuti sosialisasi, untuk kemudian melakukan pemilihan kader pengelola Bank Sampah. Dalam kegiatan ini, tim dan peserta melakukan demonstrasi terkait mekanisme pengelolaan Bank Sampah juga menentukan nama untuk Bank Sampah yang akan dibentuk.

Kegiatan Pengabdian Kepada Masyarakat yang ketiga berlangsung pada hari Senin, tanggal 24 September 2018 pukul 13.00 WIB hingga pukul 16.30 WIB berlokasi di tempat pelelangan ikan. Kegiatan ini merupakan kegiatan inti dari PKM yang dilakukan di Desa Segara Jaya, yaitu pembentukan Bank Sampah sekaligus penimbangan pertama bagi Bank Sampah Jembatan Cinta Desa Segara Jaya Kecamatan Tarumajaya Kabupaten Bekasi Jawa Barat.

\subsection{Kegiatan Pengabdian Kepada Masyarakat Tahap Pertama}

Pada kegiatan Pengabdian Kepada Masyarakat tahap ini tim bersama mitra (Pokmaswas HIU Pantai PAL Jaya) mengundang masyarakat untuk turut serta dalam sosialisasi tentang perlindungan kawasan pesisir Pantai PAL Jaya Desa Segara Jaya, Tarumajaya, Bekasi mengenai lingkungan pesisir dan bahaya sampah bagi kehidupan manusia, ekosistem pesisir dan laut, serta pengelolaan sampah dalam bentuk bank sampah. Persiapan kegiatan dimulai dari pukul 09.00 WIB, dengan meminta bantuan kepada bapak RW (Pak Kodi) untuk kembali mengajak masyarakat agar berkenan hadir dalam sosialisasi yang akan dilaksanakan. Karena hingga kegiatan akan dimulai sesuai dengan jadwal yang direncanakan yaitu pukul $10.00 \mathrm{WIB}$, ruangan aula desa masih sepi. Akhirnya sekira pukul 09.30 WIB Pak Kodi mengumumkannya lewat pengeras suara musala. Kemudian masyarakat pun segera berdatangan dan mengisi daftar hadir kemudian diberi snack dan kertas pretes yang telah disediakan oleh tim. Dalam pengisian daftar hadir dan penyebaran soal pretest, tim dibantu oleh tiga orang mahasiswa, dan tepat pada pukul 10.00 WIB sosialisasi pun dimulai dengan dipandu oleh pembawa acara Ibu Shahibah Yuliani, S. Sos., M. Pd.

Setelah kegiatan dibuka oleh pengatur acara, para peserta yang awalnya asik berbincang sambil menyantap kudapan yang telah disediakan mulai tenang dan memperhatikan dengan fokus. Kemudian kegiatan dilanjutkan dengan sambutan dari Kepala UPTD. Dalam sambutannya ini beliau menyampaikan tentang dampak positif dan dampak negatif dari pariwisata mangrove bagi masyarakat sekitar. Selanjutnya yaitu sambutan dari ketua pelaksana Pengabdian Kepada Masyarakat yaitu Ibu Dr. Dian Alfia Purwandari, M. Si. disampaikan kepada para peserta terkait perlindungan kawasan pesisir Pantai PAL Jaya Desa Segara Jaya, Tarumajaya, Bekasi mengenai lingkungan pesisir dan bahaya sampah bagi kehidupan manusia, ekosistem pesisir dan laut.

Acara selanjutnya merupakan inti dari kegiatan Pengabdian Kepada Masyarakat tahap satu, yaitu mengenai pengelolaan sampah dalam bentuk bank sampah. Dalam penyampaian materi ini mendatangkan ahli sekaligus praktisi dalam pengelolaan bank sampah, yaitu Ibu Naning dan Ibu Endah. Pada kegiatan ini para peserta cukup antusias dan terjalin komunikasi dua arah, seperti saat pemateri bertanya kepada para peserta terkait materi yang tengah disampaikan. Di antara para peserta mencoba untuk menjawab pertanyaan yang disampaikan oleh pemateri, mereka pun menyadari bahwa lingkungan tempat mereka tinggal penuh dengan sampah.

Adapun materi yang disampaikan oleh pemateri yaitu tentang 3 R (Reduce, Reuse, Recycle), kemudian jenisjenis sampah, dan yang dibutuhkan dalam persiapan bank sampah. Dalam pemaparannya pemateri memberikan contoh tentang bagaimana cara mengumpulkan dan memilah sampah anorganik, seperti plastik, kertas, kardus, alumunioum foil, dll. juga terkait harga sampah berdasarkan jenisnya.

Setelah selesai paparan, kemudian pemateri meminta tiga orang peserta untuk menjadi volunteer sebagai kader untuk simulasi alur Bank Sampah. Akhrinya terpilihlah dua orang peserta perempuan dan satu orang peserta lakilaki. Masing-masing dari mereka memperoleh tugas sebagai pengelola pencatatan, pengelola penimbangan, dan pengelola pemilahan. Kemudian diminta juga peserta untuk menjadi volunteer sebagai nasabah dan dua peserta sebagai pembantu yang mengumpulkan sampah yang ada di dalam ruangan kemudian memilahnya serta memisahkannya ke dalam wadah yang sudah disediakan. Aktivitas simulasi ini difasilitasi oleh pemateri kedua, yaitu Ibu Endah.

Pemateri pun memulai simulasi dengan terlebih dahulu mengenalkan jenis-jenis sampah. Kemudian dilanjutkan dengan contoh alur Bank Sampah, pertama tentang pemilahan sampah kering seperti plastic, plastic daun (plastic yang tipis) dikumpulkan bersama jenis plastic lainnya. Begitupun dengan sampah jenis kertas, seperti kertas duplex, kertas jagung, dan kertas lainnya dikumpulkan berdasarkan jenis yang serupa. Dalam memilah sampah botol plastic, dikelompokkan berdasarkan bagian-bagiannya seperti tutup botol dikumpulkan pada wadah terpisah, begitupun plastic segelnya juga dikumpulkan di tempat terpisah. Kemudian botolnya diremas dan dikumpulkan di tempat 
terpisah. Untuk botol kecap tidak perlu diremas dan penyimpannya digabung dan dikumpulkan bersama botol-botol plastic lainnya yang sejenis. Untuk sampah jenis kotak minuman, seperti bekas the atau susu kemudian dikeluarkan sisa-sisa airnya, dilepas tutupnya, lalu kotaknya dilipat, dan disimpan di tempat yang berbeda. Jenis botol beling dihitung persatuan, sedangkan jenis gelas beling bening dihitung perkilo. Panic-panci rusak atau perabotan rumah tangga bisa juga ditabung di Bank Sampah. Kemudian buku-buku tulis anak yang sudah tidak terpakai kemudian dibuka jilidnya, dan dikumpulkan dengan sampah kertas yang sejenis. Bisa dilihat pada gambar 1 berikut

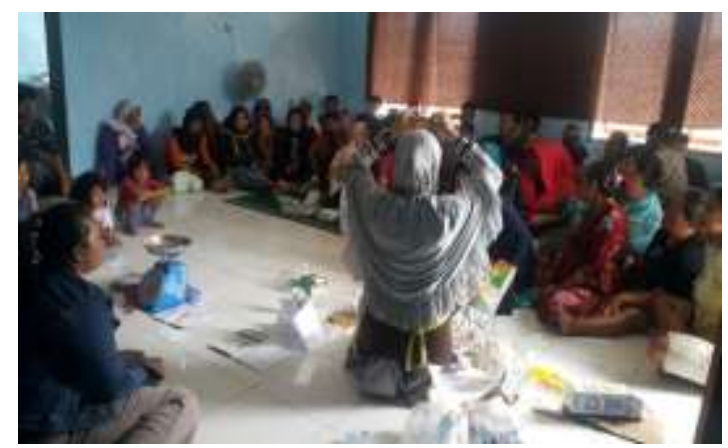

Gambar 1. Pengenalan Jenis-jenis Sampah

Dalam pengenalan jenis sampah ini, pemateri memberikan penjelasan bahwa sampah sterofoam tidak bisa ditabung di Bank Sampah. Penggunaan sterofoam sebaiknya dihindari penggunaannya karena merupakan jenis sampah yang tidak bisa diurai sehingga akan merusak lingkungan.

Pada sekitar pukul 11.14 WIB, simulasi alur Bank Smapah pun dimulai. Di sini pemateri membimbing cara-cara pencatatan, penimbangan dan pemilahan. Dalam penimbangan, gunakan kantong kresek untuk wadahnya, kemudian tuliskan jumlah beratnya dalam satuan kilogram dan harga per-item. Kemudian setelah ditimbang barulah sampah-sampah yang sudah terkumpul tersebut dipilah berdasarkan jenisnya.

Saat simulasi ini, suasana ruangan semakin ramai, ada juga beberapa peserta yang asik mengobrol namun obrolannya masih dalam tema yang sedang dibahas. Kemudian saat ditanya tentang komitmen Bank Sampah, mereka secara serentak menyatakan komitmen untuk mengumpulkan sampah dan dengan tegas menyatakan janjinya untuk terlibat dalam Bank Sampah.

Setelah selesai sesi ini, kemudian dilanjutkan dengan penyampaian kesepakatan oleh ketua pelaksana Pengabdian Kepada Masyarakat, yaitu pisahkan, sortir, kemudian bersihkan dan simpan sampah-sampah untuk kemudian ditabung pada Bank Sampah yang akan dibentuk di Desa Segara Jaya. Tim pun menantang para peserta terkait nasabah yang mampu mengumpulkan dan menabung sampah terbanyak pada penimbangan perdana, maka akan memperoleh hadiah dari tim pelaksana. Kemudian peserta pun diberi tahu bahwa akan ada buku tabungannya bagi siapa saja yang menajdi nasabah dari Bank Sampah.

Kemudian Pengabdian Kepada Masyarakat tahap pertama pun selesai dengan diakhiri oleh tanya-jawab dengan peserta sosialisasi. Pertanyaan pertama diajukan oleh Pak Kodi, yaitu tentang pengelolaan sampah organic di Desa ini bagaimana, karena tempat untuk pembuangan sampahnya pun tidak ada. Kemudian pemateri pertama memberikan jawaban bahwa untuk menanggulangi hal ini bisa dengan pembuatan composting takakura, setiap sampah organic dimasukkan ke dalam drum, kemudian nanti akan keluar kompos cair. Jawaban berikutnya dari ketua pelaksana yaitu bisa dengan melakukan kerjasama dengan pihak UPTD, bisa juga dengan cara biogas. Di akhir sesi, kemudian Pak Jauhari dari UPTD menegaskan tentang $3 \mathrm{~K}$ yaitu Kemauan, Kemampuan, dan Konsisten. Masyarakat harus meningkatkan kemauan dan melihat kemampuan kita, jika merasa tidak mampu maka belajar, tanya google, baca buku, dll.serta konsisten. Dalam hal ini masyarakat harus berpikir tentang pengelolaan sampah sehingga bisa menghasilkan secara ekonomis, hal ini terkait dengan Bank Sampah.

Sesi pun diakhiri dengan kesepakatan pertemuan berikutnya untuk berkumpul kembali dan membicarakan tentang kelanjutan Bank Sampah.

\subsection{Kegiatan Pengabdian Kepada Masyarakat Tahap Kedua}

Kegiatan tahap kedua ini yaitu pembentukan kader Bank Sampah dan kesepakatan nama Bank Sampah yang akan digunakan. Kegiatan ini dilaksanakan pada hari Rabu, tanggal 19 September 2018 pukul 10.00 WIB bertempat di Aula Desa Segara Jaya dihadiri oleh 15 orang peserta.

Kegiatan yang pertama yaitu langsung kepada pembentukan kader Bank Sampah Jembatan Cinta, nama ini dipilih berdasarkan kesepakatan peserta dan berdasarkan keberadaan objek wisata Jembatan Cinta di Pantai PAL Jaya Segara Jaya dengan difasilitasi oleh Ibu Dr. Dian Alfia Purwandari, M. Si. Terpilihlah lima orang kader Bank Sampah Jembatan Cinta, dengan ketua yaitu Ibu Santi, Bendahara Ibu Masulah, Seksi Pencatatan Ibu Pipit, Seksi Pendaftaran Ibu Ani, dan Sekdi penimbangan adalah Ibu Lia. Ilustrasi pembekalan kader yang terpilih dapat dilihat pada gambar 2 berikut.

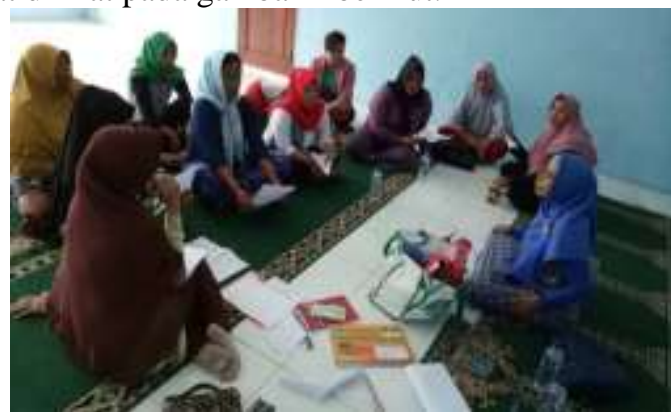

Gambar 2. Pembekalan Kader Bank Sampah Jembatan Cinta 
Kemudian sesi beralih kepada narasumber ke dua, yaitu pemaparan tentang kelengkapan yang diperlukan dalam Bank Sampah. Di antaranya terkait pembuatan tata tertib nasabah; pembuatan buku laporan keuangan nasabah yang dipegang oleh kader; kemudian pembuatan buku tabungan, dan pembuatan jurnal rkapan penimbangan. Pada sesi ini kader diberitahu tentang daftar harga barang (sampah) dalam satuan kilogram, kemudian harga sampah gambrud atau campuran, jika semua smapah yang terkumpul digabungkan penyimpanannya tanpa adanya pemilahan.

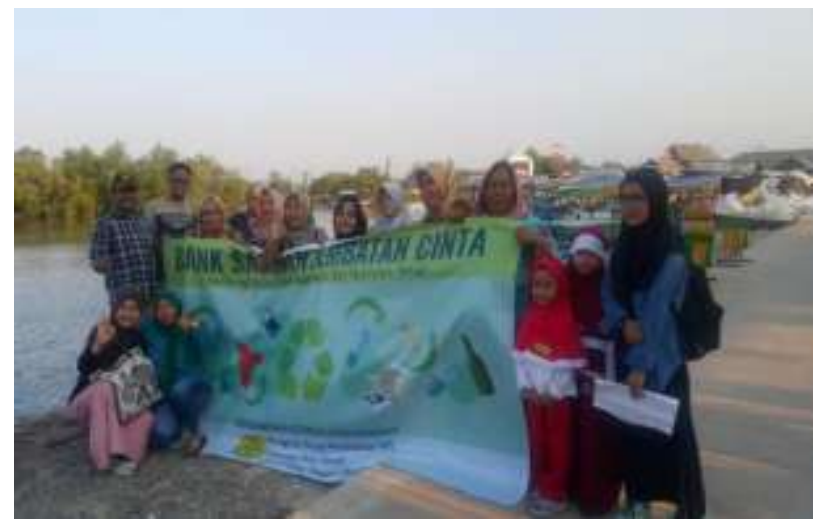

\section{Gambar 3. Tim Pengabdian Kepada Masyarakat} bersama Kader Bank Sampah Jembatan Cinta

Setelah semua peserta (kader) paham, sesi pun diakhiri dengan kesepakatan waktu penimbangan yang akan dilakukan untuk pertama kalinya. Dipilih hari Senin tanggal 24 September 2018 pukul 13.00 WIB berlokasi di Tempat Pelelangan Ikan Pantai PAL Jaya Segara Jaya Kecamatan Tarumajaya Kabupaten Bekasi.

\subsection{Kegiatan PKM Tahap Ketiga}

Hingga pukul 13.20 WIB masyarakat (kader dan calon nasabah) belum ada yang datang, baru ada dua orang saja yaitu Pak Kodi dan Pak Haji. Barulah pukul 13.30 WIB kader Bank Sampah yang sudah ditunjuk pada pertemuan sebelumnya berdatangan. Sambil menyiapkan kebutuhan yang akan digunakan dalam penimbangan perdana ini, tim melakukan diskusi bersama kader dan beberapa warga yang sudah hadir. Di sini tim mengalami kendala, yaitu terkait telah terjadinya kesalahpahaman di antara warga menyikapi pertemuan sebelumnya yang tidak melibatkan semua warga. Sehingga berdampak pada kehadiran warga yang jumlahnya tidak sesuai dengan saat pertemuan pertama.

Berbagai asumsi pun muncul dari warga yang menggiring kami dalam pencarian dan penggalian masalah yang terjadi di antara warga terkait Bank Sampah. Sedikitnya warga yang berminat untuk mengikuti penimbangan ini dilatarbelakangi oleh beberapa alasan, di ataranya:

1. Sudah ada sebagian warga yang telah menjual sampah mereka kepada tukang rongsokan, karena meminjam uang sehingga sebagai pembayarannya dilakukan dengan menukar barang bekas yang sudah mereka kumpulkan.

2. Masyarakat terbagi menajdi dua kubu, akibat pemilihan kades yang baru berlangsung beberapa waktu lalu.

3. Rata-rata masyarakat di sini ingin langsung ada dalam bentuk uang saat melakukan penimbangan sampah, bukan untuk menabung/menimpannya.

4. Pengepul di daerah ini sudah banyak, seperti dari pembuangan proyek, ada ibu-ibu atau disebutnya kuli (ngepul barang-barang atau sampah sisa proyek dengan meminta bantuan masyarakat di sini)

5. PKK (Pemberdayaan Kesejahteraan Keluarga) sedang berada pada masa transisi sehingga masih belum aktif karena sedang pergantian kepengurusan.

Sehingga timbulah cara pemecahan masalah yang sedang dihadapi yaitu dengan mengumpulkan sampah dari masyarakat yang mempunyai warung, kemudian berunding dengan Pak Imo dan Pak Imang (petugas kebersihan) agar mengumpulkan sampah anorganik untuk ditabung di Bank Sampah Jembatan Cinta. Kemudian cara berikutnya yaitu dengan sistem jemput bola, tim (Shahibah Yuliani dan Nova Scorviana) bergerilya mengunjungi tiap-tiap rumah warga untuk diminta partisipasi dalam penimbangan perdana yang dilakukan di Bank Sampah Jembatan Cinta.

Cara seperti ini cukup efektif dimana kesalahpahaman antar warga terkait keterlibatan masyarakat dalam Bank Sampah menjadi terang, bahwa Bank Sampah ini ditujukan untuk semua masyarakat Desa Segara Jaya, bukan untuk kalangan tertentu saja. Sehingga dengan adanya penjelasan tersebut membuka pikiran mereka untuk tidak lagi merasa dimarginalkan, dan tentunya mereka pun mempunyai kesempatan yang sama untuk menajdi nasabah Bank Sampah. Meski kendala lain muncul yaitu saat berhadapan dengan warga yang ingin langsung memperoleh uang saat barang yang sudah mereka kumpulkan itu ditimbang. Butuh waktu untuk dapat mengubah pola pikir masyarakat tentang manfaat dari Bank Sampah.

Akhirnya tim pun kembali ke lokasi penimbangan, yang sudah dipadati oleh warga yang akan menimbang hasil pengumpulan sampahnya. Kader pun langsung sigap bekerja sesuai dengan tugasnya, dengan dibantu oleh tim ahli dan tim Pengabdian Kepada Masyarakat Universitas Negeri Jakarta. Kader yang bertugas untuk mencatat langsung menuliskan nama dari calon nasabah, begitupun dengan kader yang bertugas sebagai penimbangan dan pemilahan. Dengan semangat mereka bekerja sesuai dengan perannya masing-masing dan saling membantu, sehingga untuk penimbangan perdana ini bisa dikatakan berhasil. 


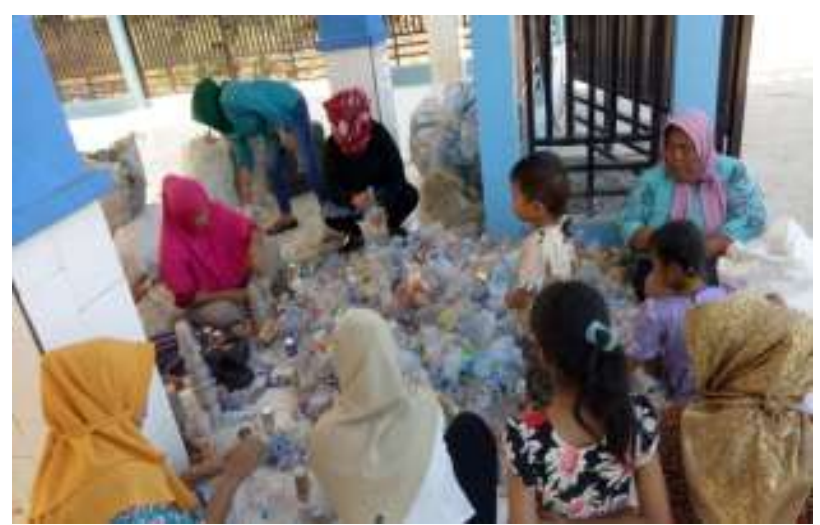

Gambar 4. Aktivitas Penimbangan Perdana Bank Sampah Jembatan Cinta

Dalam penimbangan perdana ini terkumpul berbagai jenis sampah (gambar 4) yang sudah disetor oleh para nasabah Bank Sampah Jembatan Cinta yang ada di Desa Segarajaya, di antaranya: sebanyak 28,85 kg sampah kardus terkumpul, kemudian kertas duplek sebanyak 2,2 $\mathrm{kg}$, alumunium sebanyak $1,2 \mathrm{~kg}$, gelas plastik bersih sebanyak $9 \mathrm{~kg}$, botol plastik bersih sebanyak $28 \mathrm{~kg}$, baja ringan sebanyak $12,9 \mathrm{~kg}$, emberan sebanyak $2 \mathrm{~kg}$, dan gabrug atau sampah campuran sebanyak 27,5 .

Hasil timbangan pun langsung diserahkan kepada pengepul yang sebelumnya sudah dihubungi oleh tim ahli. Dalam distribusi sampah yang terkumpul dari nasabah, tim dibantu oleh tim ahli yaitu Ibu Naning dna Ibu Endah, sehingga penimbangan Bank Sampah Jembatan Cinta yang perdana berhasil dilaksanakan.

\section{KESIMPULAN}

Kegiatan pengelolaan bank sampah Jembatan Cinta di desa Segara Jaya merupakan kegiatan yang bertujuan untuk kemandirian masyarakat secara ekonomi dan penjagaan lingkungan. Masyarakat yang sejak awal pemetaan masalah lingkungan telah dilibatkan dengan bersama sama melakukan identifikasi masalah dan identifikasi kebutuhan. Setelah menentukan pendekatan secara bersama, masyarakat diberikan pengarahan dan penyuluhan untuk memahami pentingnya pengelolaan sampah sehingga masyarakat faham dan mampu melasanakan kegiatan pengelolaan sampah dengan pendekatan bank sampah.

\section{SARAN}

Kegiatan Bank Sampah ini perlu ditingkatkan dengan kerjasama antara beberapa lembaga yaitu universitas dan Pembangkit Listrik tenaga Uap Jawa Bali yang ada di sekitar daerah Segara Jaya guna memberikan manfaat yang berkesinambungan.

\section{DAFTAR PUSTAKA}

CIFOR. 2015. "Mangrove Indonesia: Berkas Fakta: Kekayaan Nasional Dalam Ancaman." Center For International Forestry Research. https://forestsnews.cifor.org/31191/mangroveindonesia-berkas-fakta-kekayaan-nasional-dalamancaman?fnl=id.

Hardesty, Britta Denise, Julia Reisser, Ruth Sharples, and Chris Wilcox. 2011. "Understanding the Types, Sources, and at-Sea Distribution of Marine Debris in Australian Waters." 5th International Marine Debris Conference (June): 0-3.

Haywantee Ramkissoon, Betty Weiler, and Liam Smith. 2010. Investigating The Salient Factor Of Place Attachment And Its Effects On Tourists Pro Environmental Behaviour In National Parks. Melbourne, Australia.

LEE, Tsung Hung, Fen-Hauh Jan, and Chung-Chen Yang. 2013. "Environmentally Responsible Behavior of Nature-Based Tourists: Related Concepts, Measurement, and Research.” Journal of Tourism \& Hospitality 02(02): 100-115.

Lugina, Mega, Iis Alviya, Indartik Indartik, and Mirna Aulia Pribadi. 2017. "Strategi Keberlanjutan Pengelolaan Hutan Mangrove Di Tahura Ngurah Rai Bali.” Jurnal Analisis Kebijakan Kehutanan 14(1): 61-77.

Marwati, Siti. 2008. Pengelolaan Sampah Mandiri Berbasis Masyarakat.

Puhakka, Riikka. 2011. "Environmental Concern and Responsibility among Nature Tourists in Oulanka PAN Park, Finland." Scandinavian Journal of Hospitality and Tourism 11(1): 76-96.

Septiarusli, Irman Eka. 2010. "Ekosistem Mangrove Di Jawa Barat." Deep Blue Sea. https://irmaneka.wordpress.com/2010/03/30/ekosis tem-mangrove-di-jawa-barat/.

Suryani, Oleh Elvira. "Manajemen Pengelolaan Bank Sampah Di Kota Bekasi.” (2005): 63-75.

Williams, Rob, Erin Ashe, and Patrick D. O'Hara. 2011. "Marine Mammals and Debris in Coastal Waters of British Columbia, Canada." Marine Pollution Bulletin 62(6): 1303-16.

Yuliani, Shahibah, and Nova Scorviana Herminasari. 2017. "Partisipasi Masyarakat Dalam Pengelolaan Hutan Mangrove Di Desa Segarajaya, Kecamatan Tarumajaya Kabupaten Bekasi." Journal Green Growth dan Manajemen Lingkungan 6(2): 42-53.

\section{UCAPAN TERIMA KASIH}

Terima kasih kami haturkan kepada LPPM UNJ, POKMASWAS HIU Pantai PAL JAYA dan Masyarakat Segara Jaya 